\title{
UPAYA MENINGKATKAN PENDAPATAN RUMAH TANGGA PETANI KARET
}

\author{
Luis Marnisah 1), Harsi Romli 2), Tirta Jaya Jenahar 3), Ridwan Effendi4) \\ 1),2),3) Program Studi Magister Manajemen Universitas Indo Global Mandiri \\ 4) Program Studi Manajemen Informatikai Politeknik Sriwijaya \\ Jalan Jenderal Sudirman No. 629 Palembang Kode pos 30129 \\ Email : luis.uigm@yahoo.co.id ${ }^{1}$, harsi.romli@uigm.ac.id ${ }^{2)}$,profesortirtajaya@uigm.ac.id ${ }^{3)}$, \\ ridwanefendi@yahoo.com $^{4}$
}

\begin{abstract}
ABSTRAK
Rendahnya produktivitas karet rakyat menyebabkan rendahnya produksi karet dan pendapatan dari usaha tani karet juga mempengaruhi rendahnya pendapatan rumah tangga petani sedangkan kebutuhan hidup petani tetap bahkan meningkat sehingga mendorong petani meningkatkan pendapatannya dengan melakukan eksploitasi penyadapan kurang baik dan berlebihan yang menyebabkan tanaman karet menjadi rusak. Di Sumatera Selatan terdapat tanaman tua/rusak pada tahun 2014 dengan luas sekitar 129.499 ha yang secara ekonomis petani perlu mengadakan peremajaan kebun karetnya. Pentingnya topik pengabdian masyarakat ini karena melalui upaya meningkatkan kemampuan pendapatan rumah tangga petani dapat melalkukan peremajaan kebun karetnya. Pengumpulan data dengan metode survei, penarikan sampel secara acak, bertahap dan proporsional pada 12 desa sebagai perwakilan dari Kabupaten Musi Rawas, Muara Enim dan Musi Banyuasin di Sumatera Selatan di bulan Februari sampai Juli 2017 sebanyak 360 petani sampel. Analisis data menggunakan analisis finansial pendapatan petani dan analisis statistik. Hasil analisis menunjukan bahwa pendapatan rumah tangga petani dapat ditingkatkan melalui peningkatan pendapatan dengan penerapan pola tanaman sela karet, pemanfataan waktu luang dan peningkatan harga jual bahan olah karet dan terdapat perbedaan yang signifikan dengan tingkat kepercayaan $95 \%$ antara kemampuan pendapatan rumah tangga petani maju dan petani belum maju yang mampu membiayai kebutuhan rumah tangganya $95 \%$ dan $87 \%$.
\end{abstract}

Kata kunci : Pendapatan Rumah Tangga, Biaya Hidup dan Petani Karet.

\section{PENDAHULUAN}

Perkebunan karet di Sumatera Selatan mempunyai peranan yang sangat strategis karena provinsi ini merupakan daerah penghasil utama karet alam di Indonesia dimana pada tahun 2014 seluas 880.124 ha dan total produksi 628.801 ton atau 35,66 \% dari produksi karet Indonesia dan pada tahun 2017 meningkat menjadi 928.182 ha dan total produksi 641.232 ton atau 45,36\% dari produksi karet Indonesia. Kontribusi karet terhadap Produk Domestik Regional Bruto (PDRB) Sumatera Selatan sebesar Rp 2.861 juta atau 10,61 \% dari total PDRB tanpa migas Sumatera Selatan. Volume ekspor karet Sumatera Selatan sebesar 527,37 juta ton yang merupakan masukan devisa negara sebesar US \$ 618,2 juta atau 73,66 \% dari ekspor komoditi perkebunan Sumatera Selatan. Selain itu perkebunan karet sebagai sumber pendapatan dan penghidupan sekitar 700 ribu rumah tangga dan 100 ribu karyawan perusahaan perkebunan yaitu sekitar 3,2 juta jiwa atau 47,8 \% dari total penduduk Sumatera Selatan (Pemerintah Provinsi Sumatera Selatan, 2015).

Pada tahun 1982 - 2014 Pemerintah Provinsi dan Kabupaten /Kota di Sumatera Selatan telah meremajakan kebun karet rakyat seluas 1.248 ha melalui Proyek bantuan parsial, namun demikian kenyataan pada tahun 2014 rata-rata produktivitas karet rakyat yaitu sekitar 0,68 ton kadar karet kering (kkk) per hektar per tahun relatif lebih rendah dibandingkan dengan produktivitas karet perkebunan besar negara sekitar 1,16 ton kkk per hektar per tahun. Apabila total produksi karet dibagi total areal perkebunan karet rakyat yang menghasilkan di Sumatera Selatan maka rata-rata produktivitas karet rakyat yaitu sekitar 1,09 ton kkk per hektar per tahun relatif masih lebih rendah dari produktivitas karet perusahaan besar negara, apalagi dibandingkan dengan produktivitas karet klon unggul dapat mencapai 2,5 ton kkk per hektar per tahun (Dinas Perkebunan Provinsi Sumatera Selatan, 2015).

Rendahnya produktivitas karet rakyat menyebabkan rendahnya produksi karet dan pendapatan dari usaha tani karet juga mempengaruhi rendahnya pendapatan rumah tangga petani sedangkan 
kebutuhan hidup petani tetap bahkan meningkat sehingga mendorong petani meningkatkan pendapatannya dengan melakukan eksploitasi penyadapan kurang baik dan berlebihan yang menyebabkan tanaman karet menjadi rusak. Di Sumatera Selatan terdapat tanaman tua/rusak pada tahun 2014 dengan luas sekitar 129.499 ha yang secara ekonomis tidak menguntungkan lagi tetapi belum diremajakan petani bahkan pada tahun 2015 cenderung terjadi peningkatan luas areal tanaman karet tua/rusak menjadi sekita 143.239 ha, walaupun ada sebagian tanaman tua/rusak yang telah diremajakan namun tingkat pertumbuhan luas areal tanaman tua/rusak tahun 1971-2014 sekitar 4,6\% per tahun sedangkan tingkat pertumbuhan peremajaan tanaman karet tahun 1971-2016 sekitar 2,1\% per tahun. (Dinas Perkebunan Provinsi Sumatera Selatan, 2015).

Salah satu tujuan peremajaan kebun karet yaitu mengganti tanaman tua/rusak dengan tanaman muda klon unggul yang memiliki produktivitas tinggi. Peremajaan kebun karet yang dilakukan petani memerlukan waktu sekitar enam tahun untuk mulai menghasilkan. Oleh sebab itu petani belum memperoleh pendapatan dari usaha tani karet sedangkan kebutuhan hidup terus berlangsung sehingga ada kemungkinan pendapatan rumah tangga petani tidak mampu membiayai kebutuhan hidupnya. Dengan kondisi ini perlu dikaji permasalahan yaitu Bagaimana upaya meningkatkan pendapatan rumah tangga petani karet?

Hasil pengabdian masyarakat ini diharapkan berguna sebagai bahan pertimbangan bagi pemerintah dalam menyusun kebijakan untuk peningkatan pendapatan dan kesejahteraan petani perkebunan karet rakyat yang merupakan sumber devisa negara, lapangan kerja, penyedia bahan baku, pemelihara kesuburan dan pengawetan tanah. Peremajaan karet merupakan upaya untuk memperbaiki produktivitas karet dan meningkatkan pendapatan petani dalam jangka panjang. Peningkatan pendapatan petani pada jangka pendek dapat dilakukan melalui memanfaatkan gawangan di antara karet dengan menanam tanaman sela. Peningkatan pendapatan petani karet dapat dicapai melalui peremajaan karet disertai pemanfaatan lahan di antara tanaman karet melalui pola usaha tani terpadu (Tjasadihardja et al.,1995).

Tujuan perusahaaan yaitu memperoleh keuntungan ekonomis merupakan perbedaan antara total penerimaan dengan total biaya per periode penjualan ( Hyek dalam Hyman,1997). Menurut Kadarsan (1995) pendapatan sering disama artinya dengan keuntungan, petani akan memperoleh keuntungan apabila selisih total penerimaan dengan total biaya adalah positif. Total penerimaan merupakan jumlah produksi yang dijual pada waktu penjualan dari harga yang diterima. Total penerimaan sering disebut total penjualan atau pendapatan kotor ( Seitz et al., 1994).

$$
\begin{aligned}
& \text { Pendapatan rumah tangga petani }: \mathrm{Yt}=\mathrm{Yk}+\mathrm{Yl}+\mathrm{Yd} \\
& \text { Keterangan }: \mathrm{Yt}=\text { Pendapatan rumah tangga }(\mathrm{Rp} / \mathrm{th}) \\
& \mathrm{Yk}=\text { Pendapatan pola tanaman sela karet }(\mathrm{Rp} / \mathrm{th}) \\
& \mathrm{Yl}=\text { Pendapatan usahatani lainnya }(\mathrm{Rp} / \mathrm{th}) \\
& \mathrm{Yd}=\text { Pendapatan di luar usahatani }(\mathrm{Rp} / \mathrm{th})
\end{aligned}
$$

Tingkat kemampuan pendapatan rumah tangga : Kr = ( Yt : Kh $) \times 100 \%$

Keterangan : $\mathrm{Kr}=$ Kemampuan pendapatan rumah tangga (\%)

Yt = Pendapatan rumah tangga (Rp/tahun)

$\mathrm{Kh}=$ Biaya kebutuhan hidup (Rp/tahun)

Upaya meningkatkan tingkat kemampuan pendapatan rumah tangga petani dapat dilakukan dengan meningkatkan pendapatan rumah tangga petani dan atau menekan biaya kebutuhan hidup petani. Peningkatan pendapatan rumah tangga petani dapat dilakukan pada pola tanaman sela karet melalui peningkatan produksi tanaman sela karet dan peningkatan produktivitas sedangkan perluasan areal garapan relatif sulit dilaksanakan kerena terbatasnya lahan yang dimiliki petani. Peningkatan pendapatan dari usahatani lainnya dapat dilakukan pada lahan usaha dipekarangan. Peningkatan pendapatan diluar usahatani melalui pemanfaatan waktu luang untuk bekerja pada lahan usahatani petani lainnya, berdagang, atau sebagai pegawai pada perusahaan atau pegawai negeri. Penekanan atau penurunan biaya kebutuhan hidup petani relatif sulit dilakukan karena kebutuhan dasar petani belum dapat terpenuhi seluruhnya oleh petani terutama kebutuhan pangan, sandang dan papan sehingga apabila terjadi peningkatan pendapatan maka petani akan meningkatkan kualitas pangan, sandang dan papan juga untuk kebutuhan sekolah, penyelenggaraan acara adat/pesta dan kegiatan sosial lainnya. 
Pengabdian masyarakat ini dikembangkan dengan pendekatan ilmiah melalui proses deduktif dan induktif. Rangkaian dari pendekatan ilmiah tersebut adalah mengidentifikasi permasalahan, menentukan tujuan dan manfaat dan merancang prosedur pengabdian masyarakat, melakukan analisis terhadap data dan informasi, serta menjelaskan data dan menarik kesimpulan. Lokasi pengabdian masyarakat adalah perkebunan karet rakyat pada ketiga kabupaten di Provinsi Sumatera Selatan yaitu Kabupaten Musi Rawas, Muara Enim.dan Musi Banyuasin. Dipilihnya wilayah penelitian Provinsi Sumatera Selatan dengan pertimbangan bahwa provinsi ini dapat mewakili provinsi lainnya di Indonesia karena Provinsi Sumatera Selatan memiliki luas areal perkebunan karet rakyat terluas di Indonesia yaitu $27.5 \%$ dari total luas areal perkebunan karet rakyat di Indonesia. Di samping itu Sumatera Selatan merupakan penghasil utama karet di Indonesia yaitu 35,6 \% dari total produksi karet Indonesia. Pengabdian masyarakat dilaksanakan mulai bulan Februari sampai dengan bulan Juli 2017.

Pengabdian masyarakat dilakukan dengan menggunakan metode survei dimana sampel diambil berdasarkan pertimbangan keterwakilan ciri-ciri fenomena populasi. Dalam analisis data pengabdian lapangan akan di dukung oleh data kuantitatif dan kualitatif, untuk mengontrol informasi yang bersifat kualitatif diperlukan informasi data kuantitatif sedangkan untuk memperjelas data kuantitatif diperlukan data kualitatif. Penarikan sampel yang dipakai adalah sampel bertahap (multi stage sampling) terhadap kabupaten, kecamatan dan desa. Dari 3 kabupaten utama penghasil karet terpilih yaitu Kabupaten Musi Rawas, Muara Enim dan Musi Banyuasin berdasarkan kriteria wilayah sampel: (1) luas areal karet terluas $>150.000$ ha dan (2) tanaman karet tua $>15.000$ ha. Dari setiap kabupaten tersebut dipilih 2 kecamatan dan dari setiap kecamatan dipilih 2 desa dengan kriteria sampel sebagai berikut (1) petani pemilik dan penggarap kebun karet, (2) luas lahan garapan petani $\geq 2$ ha, (3) desa tersebut tidak sedang mendapat bantuan peremajaan karet dan (4) jumlah petani terlibat mata pencarian usahatani karet terbanyak.

Dari setiap desa diambil sampel secara acak sebanyak 30 sampel petani dari kerangka sampel desa terpilih. Sampel petani belum maju dan maju ditentukan berdasarkan proporsional dari kerangka sampel petani sebanyak 360 petani sampel yaitu 210 petani belum maju dan 150 petani maju. Adapun kriteria umum sampel adalah sebagai berikut(1) petani pemilik dan penggarap kebun karet, (2) luas areal garapan petani $\geq 2$ hektar, dan (3) petani tidak sedang mendapat bantuan proyek pemerintah. Metode pengumpulan data melalui wawancara langsung dengan petani sampel meng-gunakan daftar pertanyaan yang berisikan pertanyaan-pertanyaan terbuka dan tertutup yang berkaitan dengan biaya, pendapatan, kebutuhan hidup dan alokasi tenaga kerja. Pengolahan data dengan menggunakan tabulasi data diolah dengan menggunakan program excel. Adapun langkah-langkah yang digunakan dalam menyelesaikan persoalan Masyarakat tersebut dilakukan melalui kegiatan berupa pelatihan, pendampingan, pengentasan kemiskinan, pelestariaan lingkungnan

\section{HASIL PENGABDIAN DAN PEMBAHASAN}

\subsection{Pendapatan Rumah Tangga Petani Karet}

\section{a) Rata-rata pendapatan petani sebelum peremajaan kebun karet}

Tingkat kemampuan pendapatan petani karet merupakan tingkat kemampuan pendapatan rumah tangga petani karet untuk membiayai kebutuhan rumah tangganya. Biaya kebutuhan rumah tangga petani belum maju sebesar Rp 7,652 juta per tahun dan petani maju sebesar Rp 8,973 juta per tahun. Pendapatan rumah tangga petani sebelum peremajaan kebun karet bersumber dari usahatani karet, pendapatan usahatani lainnya dan pendapatan dari luar usahatani seperti pada Tabel 1.

Tabel 1. Rata-Rata Pendapatan Rumah Tangga Petani Sebelum Peremajaan Karet Kebun Tahun 2015

\begin{tabular}{|c|l|c|c|c|c|c|c|}
\hline \multirow{2}{*}{ No } & \multirow{2}{*}{ Sumber Pendapatan } & \multicolumn{7}{|c|}{ Pendapatan Rumah Tangga (Rp juta) } \\
\cline { 3 - 8 } & & $\begin{array}{c}\text { Petani } \\
\text { Belum Maju }\end{array}$ & $\mathbf{\%}$ & Petani Maju & $\mathbf{\%}$ & Rata-rata & \% \\
\hline 1. & Usahatani karet & 9,967 & 70,05 & 5,093 & 73,67 & 12,103 & 71,46 \\
2. & Usahatani lainnya & 2,611 & 18,35 & 2,968 & 14,49 & 2,860 & 16,89 \\
3. & Di luar usahatani & 1,650 & 11,60 & 2,425 & 11,84 & 1,973 & 11,65 \\
\hline \multicolumn{2}{|c|}{ Jumlah } & 14,228 & 100 & 20,486 & 100 & 6,936 & 100 \\
\hline
\end{tabular}


Pada Tabel 1 dapat diketahui bahwa rata-rata pendapatan rumah tangga petani belum maju Rp 14,228 juta per tahun dan petani maju $\mathrm{Rp} 20,486$ juta per tahun. secara keseluruhan rata-rata pendapatan rumah tangga petani karet $\mathrm{Rp} 16,936$. Rata-rata pendapatan rumah tangga petani belum maju dan petani maju mampu membiayai kebutuhan rumah tangganya. Tingkat kemampuan pendapatan petani belum maju $186 \%$, sedangkan tingkat kemampuan pendapatan petani maju 228 $\%$.

b) Rata-rata pendapatan petani sesudah peremajaan kebun karet

Pendapatan rumah tangga petani belum maju dan petani maju yang sesudah melakukan peremajan kebun karet tahun 2015 dapat dilihat pada Tabel 2 dan Tabel 3.

Tabel 2. Pendapatan Rumah Petani Belum Maju

Yang Sudah Melakukan Peremajaan Kebun Karet Tahun 2015.

\begin{tabular}{|c|c|c|c|c|c|c|c|c|}
\hline \multirow[t]{2}{*}{ No } & \multirow{2}{*}{$\begin{array}{c}\text { U r a I a n } \\
\text { (Rp 1000) }\end{array}$} & \multicolumn{7}{|c|}{ Umur Tanaman Karet Tahun ke (Rp 1000) } \\
\hline & & $\mathbf{0}$ & 1 & 2 & 3 & 4 & 5 & 6 \\
\hline \multirow{5}{*}{1} & $\begin{array}{l}\text { Pendapatan RT } \\
\text {-Pola tanam sela }\end{array}$ & - & 2.494 & 2.048 & 1.591 & 225 & - & - \\
\hline & -Usahatani lainnya & - & 2.611 & 2.611 & 2.611 & 2.611 & 2.611 & 2.611 \\
\hline & -Di luar usahatani & - & 1.650 & 1.650 & 1.650 & 1.650 & 1.650 & 1.650 \\
\hline & -Nilai kayu karet & 1.500 & & - & - & - & & - \\
\hline & Jumlah & 1.500 & 6.755 & 6.309 & 5.852 & 4.486 & 4261 & 4.261 \\
\hline 2 & $\begin{array}{l}\text { Biaya peremajaan } \\
\text { ke- bun karet }\end{array}$ & $1.297,5$ & 101,5 & 109 & 139,5 & 178,5 & 214,5 & 392 \\
\hline 3 & Sisa pendapatan RT & 202,5 & $6.653,5$ & 6.200 & $.712,5$ & $4.307,5$ & $4.046,5$ & 3.869 \\
\hline 4 & Kebutuhan RT & - & 7.652 & 7.652 & 7.652 & 7.652 & 7.652 & 7.652 \\
\hline 5 & $\begin{array}{l}\text { Kermampuan } \\
\text { pendapatan RT (\%) }\end{array}$ & - & 87 & 81 & 75 & 56 & 53 & 51 \\
\hline
\end{tabular}

Pada Tabel 2 dan Tabel 3 dapat dijelaskan bahwa biaya peremajaan kebun karet tahun ke-0 dapat dipenuhi dari penjualan kayu karet, sedangkan biaya peremajaan pada tahun ke-1, ke-2 dan ke-3 dapat dipenuhui dari pendapatan pola tanaman sela karet. Biaya peremajaan kebun karet tahun ke4 sampai ke-6 tidak dapat dipenuhi dari usahatani pola tanaman sela karena tanaman sela tidak dapat ditanami lagi diantara gawangan tanaman karet kecuali sisa tanaman pisang dan nenas yang tidak terawat tetapi masih dapat dipanen. Biaya peremajaan kebun karet tahun ke-4 samapai ke- 6 diupayakan dari pendapatan usahatani lainnya atau pendapatan dari luar usahatani.

Tabel 3. Pendapatan Rumah Tangga Petani Maju

Yang Sudah Melakukan Peremajaan Kebun Karet Tahun 2015.

\begin{tabular}{|c|c|c|c|c|c|c|c|}
\hline \multirow{2}{*}{ No } & \multirow{2}{*}{$\begin{array}{c}\text { Uraian } \\
\text { (Rp. 1000) }\end{array}$} & \multicolumn{6}{|c|}{ Umur Tanaman Karet Tahun ke (Rp 1000) } \\
\hline & & $\mathbf{0}$ & 1 & 2 & 3 & 4 & 5 \\
\hline 1 & Pendapatan RT & & & & & & \\
\hline & -Pola tanam sela & - & 3.382 & 2.490 & 2.619 & 225 & - \\
\hline & -Usahatani lainnya & - & 2.426 & 2.426 & 2.426 & 2.426 & 2.426 \\
\hline & -Di luar usahatani & - & 2.968 & 2.968 & 2.968 & 2.968 & 2.968 \\
\hline & - Nilai kayu karet & 2.100 & - & - & - & - & - \\
\hline & $\mathrm{Jumlah}$ & 2.100 & 8.776 & 7.884 & 7.013 & 5.619 & 5.394 \\
\hline 2 & $\begin{array}{l}\text { Biaya peremajaan } \\
\text { ke- bun karet }\end{array}$ & $2.026,5$ & 201 & 305 & 409 & 513 & 718,75 \\
\hline 3 & Sisa pendapatan $\mathrm{R}$ & 72,5 & 8.575 & 7.579 & 6.604 & 5.106 & $4.675,25$ \\
\hline 4 & Kebutuhan RT & - & 8.974 & 8.974 & 8.974 & 8.974 & 8.974 \\
\hline 5 & $\begin{array}{l}\text { Kermampuan } \\
\text { pendapatan RT (\%) }\end{array}$ & - & 95 & 84 & 73 & 57 & 52 \\
\hline
\end{tabular}

c) Tingkat Kemampuan Pendapatan Petani Karet

Adapun klasifikasi tingkat kemampuan pendapatan rumah tangga petani untuk membiayai kebuuhan rumah tangganya seperti pada Tabel 4. 
Tabel 4. Tingkat Kemampuan Pendapatan Rumah Tangga Petani Karet Tahun 2015

\begin{tabular}{|c|c|c|c|c|c|c|c|}
\hline \multirow[b]{2}{*}{ No } & \multirow{2}{*}{$\begin{array}{l}\text { Kemampuan Membiayai } \\
\text { Kebutuhan Rumah } \\
\text { Tangga }\end{array}$} & \multicolumn{2}{|c|}{ Petani Belum Maju } & \multicolumn{2}{|c|}{ Petani Maju } & \multicolumn{2}{|c|}{ Total } \\
\hline & & $\begin{array}{c}\text { Rumah } \\
\text { tangga }\end{array}$ & $\%$ & $\begin{array}{l}\text { Rumah } \\
\text { tangga }\end{array}$ & $\%$ & $\begin{array}{l}\text { Rumah } \\
\text { tangga }\end{array}$ & $\%$ \\
\hline 1 & Tidak mampu $\mathrm{Kr}<100 \%$ & 26 & 12,38 & 8 & 5,33 & 34 & 9,44 \\
\hline 2 & Mampu Kr $\geq 100 \%$ & 184 & 87,62 & 142 & 94,67 & 326 & 90,56 \\
\hline & Jumlah & 210 & 100 & 150 & 100 & 360 & 100 \\
\hline
\end{tabular}

Keterangan : $\mathrm{Kr}=(\mathrm{Yt} / \mathrm{Bk}) \times 100 \%$

$\mathrm{Kr}=$ Kemampuan membiayai kebutuhan rumah tangga (\%)

$\mathrm{t}=$ Pendapatan rumah tangga (Rp/tahun)

$\mathrm{Bk}=$ Biaya kebutuhan rumah tangga $(\mathrm{Rp} /$ tahun $)$

Pada Tabel 4 dapat dijelaskan bahwa sebanyak 94,67 \% petani maju mampu membiayai kebutuhan rumah tangganya dan sebanyak 87,62 \% petani belum maju mampu membiayai kebutuhan rumah tangganya atau secara keseluruhan 90,56 \% petani mampu membiayai kebutuhan rumah tangganya. Rata-rata tingkat kemampuan pendapatan rumah tangga petani maju $231 \%$ dan petani belum maju $179 \%$. Dari hasil analisis statistik uji nilai tengah signifikan pada tingkat kepercayaan $90 \%$ dengan thitung 1,81 dan F hitung 1,76. Ini berarti tingkat kemampuan pendapatan rumah tangga petani maju berbeda dengan tingkat kemampuan pendapatan rumah tangga petani belum maju atau tingkat kemampuan pendapatan rumah tangga petani maju $129 \%$ dari tingkat kemampuan petani belum maju untuk membiayai kebutuhan rumah tangganya.

Sebanyak 5,33 \% petani maju yang tidak mampu membiayai kebutuhan rumah tangganya dan sebanyak 12,38 \% petani belum maju yang tidak mampu membiayai kebutuhan rumah tangganya, secara keseluruhan 9,44\% petani yang tidak mampu membiayai kebutuhan rumah tangganya. Ratarata tingkat kemampuan pendapatan rumah tangga petani belum maju dan petani maju yang tidak mampu membiayai kebutuhan rumah tangganya yaitu $91 \%$ dan $92 \%$ petani yang tidak mampu membiayai kebutuhan rumah tangga ini dikarenakan petani tersebut memiliki tanaman karet yang belum menghasilkan yaitu umur 1- 6 tahun sedangkan pendapatan dari usahatani pola tanaman sela karet dan pendapatan di luar usahatani rendah dan tidak kontinyu sehingga belum cukup membiayai kebutuhan rumah tangganya. Kekurangan pendapatan rumah tangga petani untuk membiayai kebutuhan rumah tangganya menggunakan tabungan tahun yang lalu atau meminjam uang dari keluarga, pedagang pengumpul karet desa atau petani lainnya yang akan dibayar dari hasil bekerja di luar usahatani atau setelah usahatani karet mulai menghasilkan.

\subsection{Upaya Meningkatan Kemampuan Pendapatan Rumah Tangga}

\section{a) Penerapan pola tanaman sela karet}

Adapun upaya peningkatan pendapatan rumah tangga petani dapat dilakukan melalui penerapan pola tanaman sela karet dengan tanaman pangan dan hortikultura sesuai anjuran penyuluh. Penerapan pola tanaman sela karet petani belum maju dan petani maju masih dapat ditingkatkan dengan pola tanam sela karet-padi/jagung-pisang/nenas-cabai. Adapun potensi peningkatan pendapatan dan kemampuan pendapatan rumah tangga petani karet melalui penerapan pola tanaman sela karet tahun 2015 dapat dilihat pada Tabel 5

Tabel 5. Potensi Peningkatan Pendapatan Petani Karet melalui Penerapan Pola Tanaman Sela Karet Tahun 2015.

\begin{tabular}{|c|l|c|c|c|}
\hline No & $\begin{array}{l}\text { Rata-rata Pendapatan Rumah } \\
\text { Tangga }\end{array}$ & $\begin{array}{c}\text { Petani belum } \\
\text { maju } \\
\text { (Rp. Juta) }\end{array}$ & $\begin{array}{c}\text { Petani Maju } \\
\text { (Rp juta) }\end{array}$ & $\begin{array}{c}\text { Rata-rata } \\
\text { (Rp Juta) }\end{array}$ \\
\hline 1 & Pendapatan semula & 15,080 & 20,971 & 17.534 \\
\hline 2 & Potensi peningkatan & 1,968 & 2.157 & 2.047 \\
\hline 3 & Pendapatan rumah tangga & 17.048 & 23.128 & 19.581 \\
\hline 4 & Peningkatan pendapatan (\%) & 13,05 & 10,28 & 11,89 \\
\hline 5 & $\begin{array}{l}\text { Peningkatan kemampuan } \\
\text { pendapatan (\%) }\end{array}$ & 21,95 & 24,04 & 22,56 \\
\hline
\end{tabular}


Pada Tabel 5 dapat dijelaskan bahwa penerapkan pola tanaman sela karet - padi - jagung - (nenas + pisang) - cabai yang baik akan meningkatkan pendapatan rumah tangga petani belum maju 127 $\%$ dari peningkatan pendapatan rumah tangga petani maju, secara keseluruhan rata-rata akan meningkatkan pendapatan rumah tangga $11,89 \%$. Penerapan pola tanaman sela karet - padi jagung - (nenas + pisang) - cabai yang baik akan meningkatkan kemampuan pendapatan rumah tangga petani maju $112 \%$ dari kemampuan pendapatan rumah tangga petani maju, secara keseluruhan rata-rata akan meningkatkan kemampuan pendapatan rumah tangga petani untuk membiayai kebutuhan rumah tangganya sebesar 29,94 \%.

b) Pemanfaatan waktu luang untuk bekerja produktif

Adapun alokasi waktu kerja rumah tangga yang tersedia, yang digunakan dan waktu luang rumah tangga petani untuk kegiatan usahatani karet, usahatani lainnya dan di luar usahatani petani karet dapat dilihat pada Tabel 6 .

Tabel 6. Alokasi Waktu Kerja Rumah Tangga Petani Karet Tahun 2015

\begin{tabular}{|c|c|c|c|c|c|c|c|}
\hline \multirow{3}{*}{ No } & \multirow{3}{*}{ Uraian } & \multicolumn{6}{|c|}{ Alokasi waktu kerja } \\
\hline & & \multicolumn{2}{|c|}{ Petani Belum Maju } & \multicolumn{2}{|c|}{ Petani Maju } & \multicolumn{2}{|c|}{ Rata-rata } \\
\hline & & $\begin{array}{c}\text { Hari Kerja } \\
\text { Pria }\end{array}$ & $\%$ & $\begin{array}{c}\text { Hari Kerja } \\
\text { Pria }\end{array}$ & $\%$ & $\begin{array}{c}\text { Hari Kerja } \\
\text { Pria }\end{array}$ & $\%$ \\
\hline 1 & Waktu untuk RT (Wk) & 239 & 24,51 & 242 & 24,82 & 240,2 & 24,63 \\
\hline 2 & Waktu istirahat (Ws) & 262 & 26,87 & 278 & 28,51 & 268,7 & 27,56 \\
\hline 3 & Waktu Produktif (Atk) & 287 & 29,44 & 308 & 31,59 & 295,8 & 30,34 \\
\hline 4 & Waktu luang (Wl) & 187 & 19,18 & 147 & 15,08 & 170,3 & 17,47 \\
\hline 5 & Waktu tersedia (Wt) & 975 & 100 & 975 & 100 & 975 & 100 \\
\hline
\end{tabular}

Pada Tabel 6 dapat diketahui bahwa rata-rata waktu kerja yang tersedia petani belum maju dan petani maju 975 hari kerja pria (hkp) per rumah tangga per tahun. Alokasi waktu yang digunakan untuk kegiatan rumah tangga dan istirahat petani maju lebih tinggi dari petani belum maju. Waktu yang digunakan untuk kegiatan produktif petani maju $308 \mathrm{hkp}$ atau 31,59\% sedangkan petani belum maju $287 \mathrm{hkp}$ atau $29,44 \%$, Waktu luang yang belum dimanfaatkan untuk kegiatan produktif petani belum maju sekitar $187 \mathrm{hkp}$ dan petani maju sekitar $147 \mathrm{hkp}$ per tahun. Waktu luang yang belum termanfaatkan untuk kegiatan produktif yang cukup besar ini sebenarnya dapat digunakan untuk meningkatkan pendapatan rumah tangga petani. Adapun potensi peningkatan pendapatan dan kemampuan ekonomis petani karet melalui pemanfaatan waktu luang untuk kegiatan produktif tahun 2015 seperti Tabel 7.

Tabel 7. Potensi Peningkatan Pendapatan Pendapatan Petani Karet melalui Pemanfaatan Waktu Luang Tahun 2015.

\begin{tabular}{|c|l|c|c|c|}
\hline No & \multicolumn{1}{|c|}{ Rata-rata pendapatan } & $\begin{array}{c}\text { Petani belum } \\
\text { Maju (Rp. 1000) }\end{array}$ & $\begin{array}{c}\text { Petani Maju } \\
\text { (Rp. 1000) }\end{array}$ & $\begin{array}{c}\text { Rata-rata } \\
\text { (Rp. 1000) }\end{array}$ \\
\hline 1. & Pendapatan semula & 15,080 & 20,971 & 17,014 \\
\hline 2. & Potensi peningkatan & 3,253 & 2,558 & 2,963 \\
\hline 3. & Pendapat rumah tangga & 18,446 & 23,529 & 20,564 \\
\hline 4. & Peningkatan pendapatan (\%) & 21,57 & 12,35 & 17,41 \\
\hline 5. & $\begin{array}{l}\text { Peningkatan kemampuan } \\
\text { pendapatan (\%) }\end{array}$ & 42,51 & 28,50 & 36,67 \\
\hline
\end{tabular}

Pada Tabel 7 dapat dijelaskan bahwa pemanfaatan waktu luang untuk kegiatan produktif akan meningkatkan pendapatan rumah tangga petani belum maju $149 \%$ dari pendapatan rumah tangga petani maju, secara keseluruhan rata-rata akan meningkatkan kemampuan pendapatan rumah tangga untuk membiayai kebutuhan rumah tangganya sebesar 36,67 \%. Pemanfaatan waktu luang untuk kegiatan produktif akan meningkatkan kemampuan ekonomis petani belum maju $127 \%$ dari peningkatan kemampuan ekonomis petani maju, secara keseluruhan rata-rata akan meningkatkan kemampuan ekonomis petani untuk membiayai peremajaan kebun karetnya sebesar 43,39\%. 
Rata-rata tingkat kemampuan pendapatan rumah tangga yang tidak mampu membiayai kebutuhan rumah tangga petani belum maju $91 \%$ dan petani maju $92 \%$, dengan penerapan pola tanam sela karet yang baik maka akan akan meningkatkan kemampuan pendapatan rumah tangga petani belum maju $21,95 \%$ dan petani maju 24,04 \% dan dengan pemanfatan waktu luang untuk bekerja produktif maka akan meningkatkan kemampuan pendapatan rumah tangga petani belum maju 42,51 \% dan petani maju 28,50 \%. Apabila dilakukan petani belum maju secara bersamaan maka akan meningkatkan kemampuan pendapatan rumah tangga petani belum maju menjadi $155 \%$ dan petani maju menjadi $144,5 \%$, dengan peningkatan ini berarti petani belum maju dan petani maju akan mampu membiayai kebutuhan rumah tangganya pada waktu melakukan peremajaan kebun karetnya karena kemampuan ekonomis petani $>100 \%$

\section{KESIMPULAN}

Dari hasil analisis dan pembahasan dapat disimpulkan bahwa :

1) Pendapatan rumah tangga petani maju dan petani belum maju untuk membiayai kebutuhan rumah tangganya dapat ditingkatkan melalui penerapan pola tanaman sela karet tumpang sari dan tumpang gilir serta pemanfaatan waktu luang untuk bekerja produktif.

2) Terdapat perbedaan yang signifikan antara tingkat kemampuan pendapatan rumah tangga petani maju dengan petani belum maju untuk membiayai kebutuhan rumah tangganya. Rata-rata tingkat kemampuan pendapatan rumah tangga petani maju 129 \% dari rata-rata tingkat kemampuan pendapatan rumah tangga petani belum maju. Petani maju dan petani belum maju yang sudah melakukan peremajaan kebun karetnya tetapi belum berproduksi tidak mampu membiayai kebutuhan rumah tangganya, sedangkan petani maju dan petani belum maju yang belum melakukan peremajaan kebun karet mampu membiayai kebutuhan rumah tangganya.

\section{DAFTAR PUSTAKA}

Dibertin. D.L. 1986. Agricultural Production Economics. Macmillan Publishing Company, New York. Dinas Perkebunan Provinsi Sumatera Selatan, 2015. Statistik Perkebunan Provinsi Sumatera Selatan Tahun 2015, Palembang.

Hyek in Hyman. D,N, 1997. Micro Economics. Irwin/Mc.Grow Hill. Boston USA : 230 - 231.

Kadarsan. W. H, 1995. Keuangan Pertanian Dan Pembiayaan Perusahaan Agribisnis. Gramedia, Jakarta.

Koutsoyiannis. A, 1987. Theory of Econometrics. An Introductory Exposition of Econometric Methods. Mac Millan Press Ltd. USA

Mubyarto, 1989. Pengantar Ekonomi Pertanian, LP3ES, Aditya Media, Yogyakarta.

Nicholson. W, 1995. Microekonomi Intermediate dan Aplikasi (terjemahan dari Intermediate Microeconomics oleh Agus Maulana). Bina Rupa. Aksara, Jakarta.

Raghavan, 1988. Micro Economics. Ideas and Analysis. Gian Publishing House Delhi.

Samuelson. P.A, and Williams. D. Nordhous, 1986. Economics. Mc Graw Hill International Editions. Singapore.

Seitz.W.D, G.O.Nelson and H.G.Halcrow, 1994. Economics of Resources, Agriculture and Food. Mc.Grow Hill inc. New York : $70-73$.

Tjasadihardja. A, C. Nancy, G. Wibawa, M. J. Rosyid dan A. Arsyad, 1995. Usaha Meningkatkan Pendapatan Petani melalui Peremajaan Karet secara Swadaya dengan Pola Usahatani Terpadu. Warta Pusat Penelitian Karet. Vol. 14 (3) : 147-158. 